\title{
Laboratory capacity for diagnosis of foot-and-mouth disease in Eastern Africa: implications for the progressive control pathway
}

\author{
Alice Namatovu ${ }^{1,2}$, Sabenzia Nabalayo Wekesa ${ }^{3,4}$, Kirsten Tjørnehøj ${ }^{5}$, Moses Tefula Dhikusooka', \\ Vincent B Muwanika ${ }^{3}$, Hans Redlef Siegsmund ${ }^{6}$ and Chrisostom Ayebazibwe ${ }^{1 *}$
}

\begin{abstract}
Background: Accurate diagnosis is pertinent to any disease control programme. If Eastern Africa is to work towards control of foot-and-mouth disease (FMD) using the Progressive Control Pathway for FMD (PCP-FMD) as a tool, then the capacity of national reference laboratories (NRLs) mandated to diagnose FMD should match this task. This study assessed the laboratory capacity of 14 NRLs of the Eastern Africa Region Laboratory Network member countries using a semi-structured questionnaire and retrospective data from the World Reference Laboratory for FMD annual reports and Genbank ${ }^{\circledR}$ through National Centre for Biotechnology Information for the period 2006-2010.

Results: The questionnaire response rate was 13/14 (93\%). Twelve out of the 13 countries/regions had experienced at least one outbreak in the relevant five year period. Only two countries (Ethiopia and Kenya) had laboratories at biosecurity level 3 and only three (Ethiopia, Kenya and Sudan) had identified FMD virus serotypes for all reported outbreaks. Based on their own country/region assessment, 12/13 of these countries/regions were below stage 3 of the PCP-FMD. Quarantine (77\%) and vaccination (54\%) were the major FMD control strategies employed. The majority (12/13) of the NRLs used serological techniques to diagnose FMD, seven used antigen ELISA and three of these $(25 \%)$ also used molecular techniques which were the tests most frequently requested from collaborating laboratories by the majority (69\%) of the NRLs. Only 4/13 (31\%) participated in proficiency testing for FMD. Four (31\%) laboratories had no quality management systems (QMS) in place and where QMS existed it was still deficient, thus, none of the laboratories had achieved accreditation for FMD diagnosis.
\end{abstract}

Conclusions: This study indicates that FMD diagnostic capacity in Eastern Africa is still inadequate and largely depends on antigen and antibody ELISAs techniques undertaken by the NRLs. Hence, for the region to progress on the PCP-FMD, there is need to: implement regional control measures, improve the serological diagnostic test performance and laboratory capacity of the NRLs (including training of personnel as well as upgrading of equipment and methods, especially strengthening the molecular diagnostic capacity), and to establish a regional reference laboratory to enforce QMS and characterization of FMD virus containing samples.

\section{Background}

Foot-and-mouth disease (FMD) is a highly contagious, acute, vesicular disease of cloven-hoofed domestic and wild animals [1]. The disease poses significant constraints through reduced productivity and limitation of international trade in live animals and their products $[2,3]$. The causal agent, foot-and-mouth disease virus

\footnotetext{
* Correspondence: cayebazibwe@gmail.com

${ }^{1}$ National Animal Disease Diagnostics and Epidemiology Centre, Ministry of Agriculture Animal Industry and Fisheries, P. O. Box 513, Entebbe, Uganda Full list of author information is available at the end of the article
}

(FMDV), belongs to the genus Aphthovirus, in the family Picornaviridae [4] and exists in seven serotypes; O, A, C, Asia 1, SAT 1, SAT 2 and SAT 3, with all except Asia 1 having occurred in Africa [5,6]. In Eastern Africa, serotypes O, A, SAT 1 and SAT 2 are still in circulation [7-10]. Serotype C was last diagnosed in Kenya in 2004 $[11,12]$ while SAT 3 was last isolated from African buffalos (Syncerus caffer) in Uganda in 1997 [13]. However, the FMD situation is constantly evolving necessitating regular typing of currently circulating FMDV strains if effective control measures are to be implemented [14].

\section{Biomed Central}




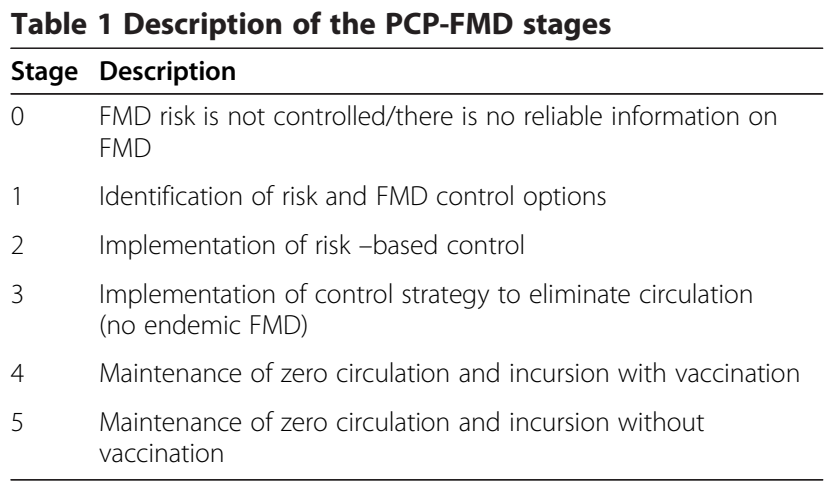

The Progressive Control Pathway for FMD (PCPFMD) tool was developed by FAO/OIE to assist endemic countries to reduce progressively the impact of FMD [15], and consists of six stages (0-5) as shown in Table 1 [14]. The main activities of the PCP-FMD tool include: monitoring circulating serotypes, vaccination and enhancing bio-security. In Eastern Africa, quarantine and vaccination are among the existing FMD control strategies $[16,17]$, however, the effectiveness of quarantine is limited by inadequate facilities and very weak law enforcement against animal movements [15,17]. Restriction of animal movements is complicated by social customs (communal grazing, dowry and pastoralism) [17] and both legal and illegal cross-border animal movements. In addition, although, wildlife have been shown to play a role as a maintenance host for FMDV [7], fences and vaccination zones around the national parks are absent. Thus, uncontrolled animal movements are still a major risk for spreading FMD [18] and transboundary mobility of FMDV has been proven between East African countries $[9,19]$. Hence, there is a need for an integrated regional approach to FMD control [5].

In the absence of the capacity to control FMD through animal movement restrictions and other biosecurity measures, vaccination remains the only practical control strategy [15]. Vaccination was helpful in the control and eradication of FMD from Europe (up to1991-1992) [20] and, in combination with livestock movement control, helped Namibia and Botswana to obtain FMD free zones without vaccination [5]. However, despite use of vaccination in Eastern Africa in the past few decades, FMD outbreaks are still occurring regularly. The majority of countries in this region use ring vaccination of cattle after confirming an outbreak (protective vaccination) as a control strategy, as opposed to the systematic preventative vaccination schemes recommended for endemic countries. Effectiveness of ring vaccination depends on timely vaccination of all susceptible species [20] and restriction of animal movements which is difficult to accomplish. Moreover, the choice of effective vaccines should be based on matching field strains with available vaccines [21,22], however, due to the lack of the necessary tests for detection and characterisation of field strains [23], such vaccine matching is not commonly done in the region. Instead vaccination against 24 serotypes is often carried out in an attempt to ensure protection. In regions where FMD reference laboratories exist, characterisation of field strains is offered in support of regional control or eradication programmes $[24,25]$. To date, no FMD reference laboratory has been established in the Eastern Africa region to enable systematic characterisation of FMD outbreaks. Consequently, samples from outbreaks in these countries can be submitted to an OIE designated reference laboratory such as the World Reference Laboratory for FMD (WRLFMD), Pirbright, UK, for free typing. However, the extent of regional sample submission and the competences of the existing Eastern Africa NRLs for diagnosis of FMD are not well known.

In this study, we attempt to assess the laboratory capacity of the NRLs for FMD in the countries represented in the Eastern Africa Region Laboratory Network (EARLN) for FMD with regard to sampling, diagnostic tests used, quality assurance and management in pursuit of FMD control.

\section{Methods}

\section{Study area}

The study was carried out among 14 NRLs that handle diagnosis of FMD in 12 Eastern Africa member countries of the EARLN, a network which was established in 2010 mainly to develop the available regional laboratory services and to inform and guide decision makers on control of FMD. Each country had one NRL responsible for FMD diagnosis except for Somalia which encompasses three regions (Puntland, Somalia and Somaliland) with semiautonomous governments and separate NRLs. So the study endeavoured to cover the 14 NRLs in the region and Figure 1 shows the 13 NRLs that participated in the study which are the: Bujumbura National Veterinary Laboratory (BNVL) in Burundi, National Laboratory of Animal Disease Diagnostics (NLADD) in Djibouti, National Animal and Plant Health Laboratory (NAPHL) in Eritrea, National Animal Health Diagnostic and Investigation Centre (NAHDIC) in Ethiopia, FMD National Laboratory (FNL) in Kenya, Galkayo Central Laboratory (GCL) in Puntland, National Veterinary Laboratory (NVL) in Rwanda, SOWELPA Central Laboratory (SCL) in Somalia, Central Veterinary Laboratory (CVL) Hargeisa in Somaliland, Central Diagnostic Laboratory (CDL) in South Sudan, National Veterinary Research Institute (VRI) in Sudan, Central Veterinary Laboratory (CVL) in Tanzania and National Animal Disease Diagnostic and Epidemiology Centre (NADDEC) in Uganda. 


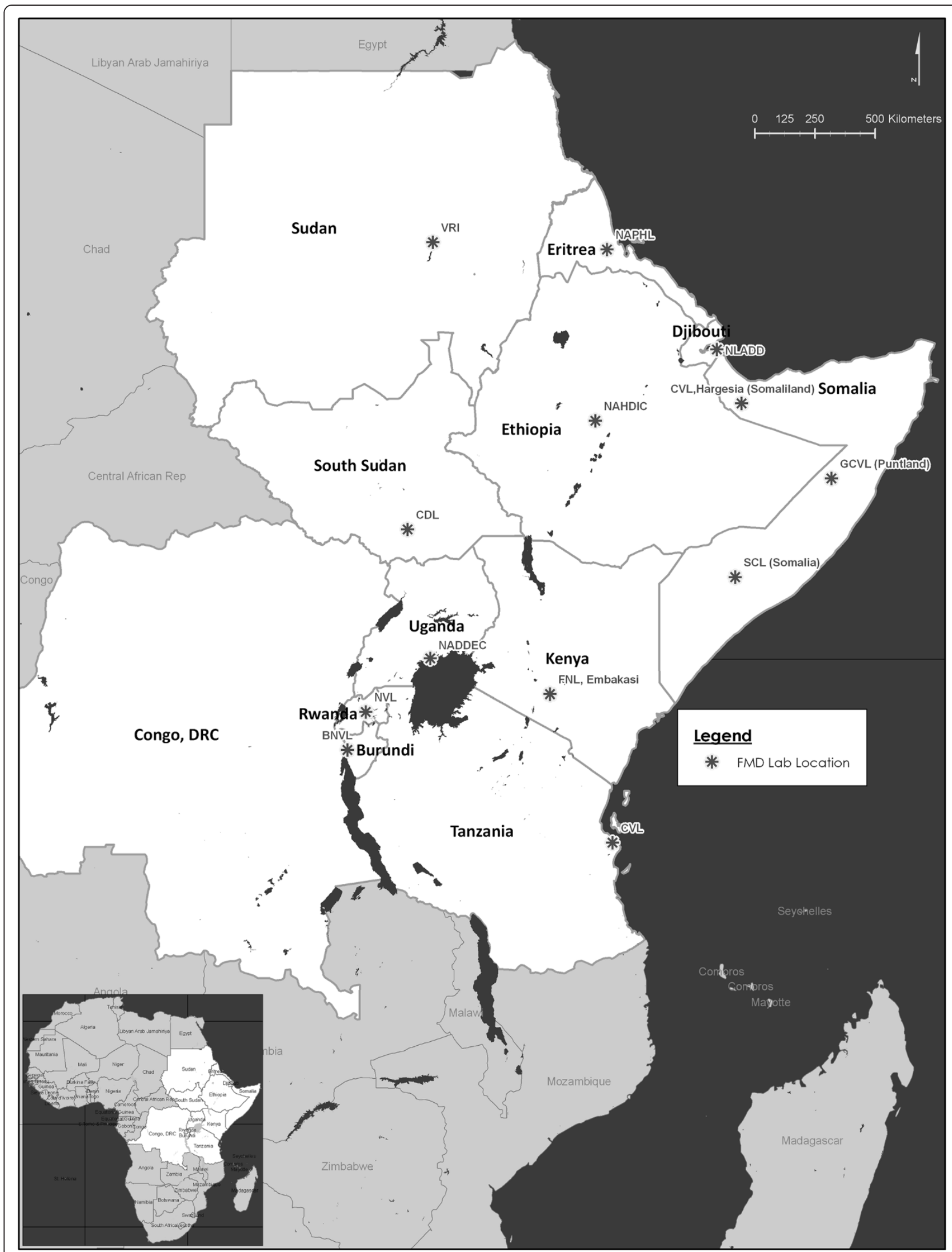

Figure 1 (See legend on next page.) 


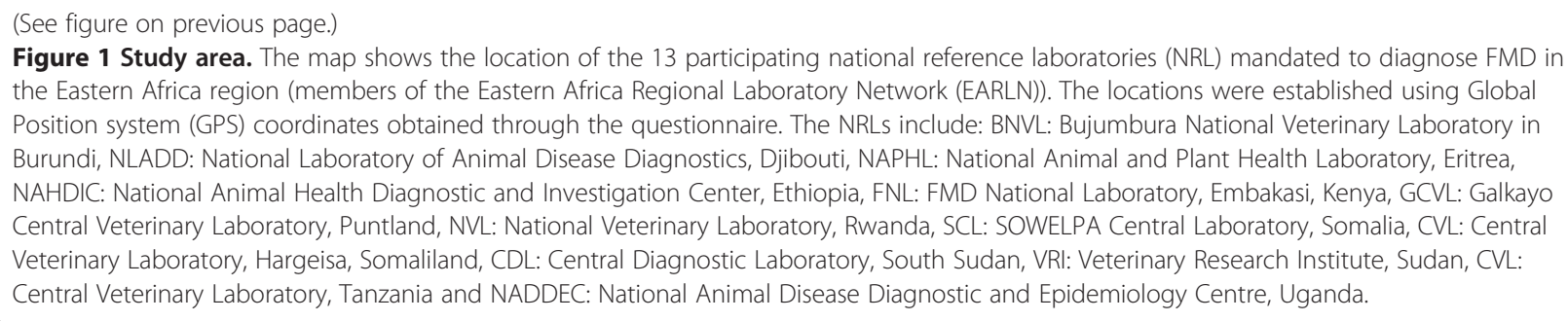

\section{Study design and data collection}

A cross-sectional purposive survey was conducted to assess the laboratory capacity for diagnosis of FMD among the NRLs in Eastern Africa. Data was collected using a semi-structured questionnaire (Additional file 1) sent electronically to one contact person for each of the 14 NRLs through the coordinator of EARLN. The general introduction to the questionnaire and any necessary clarifications were made electronically. The respondents were requested to give information related to FMD outbreaks and control strategies in their countries including: occurrence of FMD outbreaks within the time period (2006-2010), reporting of FMD outbreaks and means of communication, response time for sampling and the personnel involved in sampling, samples collected, time lag in transportation and storage of samples, stage of country on PCP-FMD, FMD control strategies, type and source of vaccines and policies for FMD control. Further, information on tests performed, available equipment for FMD diagnosis, collaborating laboratories and tests requested by NRLs, average number of samples collected annually, cost of laboratory confirmation, biosafety level (BSL), availability of QMS, accreditation status, participation in FMD proficiency testing and inter-laboratory testing within the region, servicing and calibration of equipment, monitoring of sample storage equipment, and staffing and staff development strategies was obtained.

The respondents answered by checking boxes with pre-written options, while additional information could be given in provided spaces. The filled questionnaires were returned electronically through the Coordinator of EARLN and data was entered and analysed using Microsoft Excel $^{\circledR}$. Furthermore, retrospective data on sample submission and circulating FMDV serotypes were obtained from publically available annual reports of WRLFMD, Pirbright [26] and from GenBank $^{\circledR}$, National Centre for Biotechnology Information ( NCBI) [27].

This research is part of a larger on -going strategic project 'Transboundary Animal Diseases in East Africa'. Ethical approval was granted by the Ministry of Agriculture Animal Industry and Fisheries (Reference LHE 199/01), Uganda.

\section{Results}

The questionnaire response rate was 13 out of the 14 contact persons (93\%) of the NRLs responsible for diagnosis of FMD in Eastern Africa.

\section{Annual occurrence of FMD in Eastern Africa (2006-2010)}

All countries/regions except Djibouti (12/13) had experienced at least one outbreak in the last five years and seven of these had had outbreaks in each of the 5 years. FMD outbreaks were exclusively reported by the regional zonal laboratories in Ethiopia and by Veterinary officers in three countries (Uganda, Sudan and South Sudan), while for other countries/regions (9/13) both farmers and Veterinary officers were the sources of information about FMD outbreaks to the NRLs.

Table 2 summarizes the number of years with FMD outbreaks, sample submissions to WRLFMD, and the circulating FMDV serotypes in the different countries/regions during 2006-2010 based on data from WRLFMD annual reports and NCBI's GenBank ${ }^{\circledR}$. Seven out of 12 (58\%) countries/regions that had experienced FMD outbreaks had inconsistently submitted samples to WRLFMD for typing, while only three countries (Ethiopia, Kenya and Sudan) had identified the causal FMDV serotypes for the all outbreaks identified during these 5 years.

\section{Control of FMD in Eastern Africa}

The control strategies for FMD used in these countries/ regions are shown in Table 3. Nine countries/regions indicated that they were below PCP-FMD stage 3, while one reported stage 3 , two had not yet assessed their stage and one did not indicate its stage of PCP-FMD. With the exception of South Sudan which had no FMD control strategy, two and five countries/regions relied solely on either vaccination or quarantine, respectively, while the remaining five used both vaccination and quarantine. Of the seven countries/regions that used vaccination, only Kenya and Tanzania used pre-outbreak vaccination and post outbreak ring vaccination, while four countries/regions only used post outbreak ring vaccination and one only pre-outbreak vaccination. Only Kenya and Ethiopia had vaccine production plants and with exception of Eritrea, which imported vaccines from 
Table 2 Occurrence of FMD outbreaks in Eastern Africa (2006-2010)

\begin{tabular}{|c|c|c|c|c|c|c|c|}
\hline \multirow{2}{*}{$\begin{array}{l}\text { Country/ } \\
\text { Region }\end{array}$} & \multirow{2}{*}{$\begin{array}{l}\text { Number } \\
\text { of years } \\
\text { with FMD } \\
\text { outbreaks }\end{array}$} & \multirow{2}{*}{$\begin{array}{l}\text { Sample } \\
\text { submission } \\
\text { to WRL (no. } \\
\text { of years) }\end{array}$} & \multicolumn{5}{|c|}{ FMDV serotypes identified } \\
\hline & & & 2006 & 2007 & 2008 & 2009 & 2010 \\
\hline Burundi & 5 & 0 & - & - & - & - & - \\
\hline Djibouti & 0 & 0 & - & - & - & - & - \\
\hline Eritrea & 5 & 0 & - & - & - & - & - \\
\hline Ethiopia & 5 & 4 & $\mathrm{O}^{\mathrm{ab}}$ & $\mathrm{O}^{\mathrm{a}}, \mathrm{A}^{\mathrm{a}} \mathrm{SAT1}^{\mathrm{a}}, \mathrm{SAT2}^{\mathrm{a}}$ & $O^{b}, A^{b}$ & $O^{b}, A^{b}, S A T 2^{b}$ & $\mathrm{O}^{\mathrm{b}}, \mathrm{SAT}^{\mathrm{b}}$ \\
\hline Kenya & 5 & 4 & $A^{\mathrm{b}}$, SAT1 $^{\mathrm{ab}}$ SAT $2^{\mathrm{a}}$ & $\mathrm{O}^{\mathrm{a}}, \mathrm{SAT}^{\mathrm{a}}$ & $\mathrm{O}^{\mathrm{ab}}, \mathrm{A}^{\mathrm{b}}, \mathrm{SAT} 2^{\mathrm{b}}$ & $\mathrm{O}^{\mathrm{b}}, \mathrm{A}^{\mathrm{b}}, \mathrm{SAT} 1^{\mathrm{b}}, \mathrm{SAT} 2^{\mathrm{b}}$ & $\mathrm{O}^{\mathrm{b}}, \mathrm{A}^{\mathrm{b}}$ SAT1 ${ }^{\mathrm{b}}, \mathrm{SAT} 2^{\mathrm{b}}$ \\
\hline Puntland & $\mathrm{nr}$ & 0 & - & - & - & - & - \\
\hline Rwanda & 1 & 1 & neg $^{b}$ & - & - & - & - \\
\hline Somalia & $\mathrm{nr}$ & 1 & - & - & - & neg $^{b}$ & - \\
\hline Somaliland & $\mathrm{nr}$ & 0 & - & - & - & - & - \\
\hline South Sudan* & 5 & 0 & - & - & - & - & - \\
\hline Sudan & 3 & 1 & $A^{a}$ & SAT $2^{\mathrm{ab}}$ & $\mathrm{O}^{\mathrm{a}}$, SAT $2^{\mathrm{a}}$ & - & - \\
\hline Tanzania & 5 & 2 & SAT $1^{\mathrm{b}}$ & - & - & - & $n_{e g}{ }^{b}$ \\
\hline Uganda & 5 & 2 & $\mathrm{O}^{\mathrm{a}}$ & $\mathrm{O}^{\mathrm{b}}$ & $\mathrm{O}^{\mathrm{a}}$ & $\mathrm{O}^{\mathrm{a}}$, neg $^{\mathrm{b}}$ & - \\
\hline
\end{tabular}

nr: NRL did not reply to this question, -: no FMDV serotypes identified in a particular year, neg: negative samples, ${ }^{\text {a }}$ data obtained from NCBI, Gene Bank for isolates collected during 2006-2010, b: data from annual reports of WRLFMD, Pirbright for 2006-2010. *: the lack of data from South Sudan reflects the very recent division of Sudan into Sudan and South Sudan in 2011.

Botswana Vaccine Institute (BVI), the other vaccinating countries procured non-purified vaccines from Kenya (data not shown).

\section{FMD sampling in Eastern Africa}

Sampling for FMD was done at different times depending on the purpose. Table 4 summarises sampling in the different countries/regions following reports of FMD outbreaks. In 12/13 countries/regions sampling was done during the acute phase of outbreaks and six and five of these countries/regions also sampled during the subacute and chronic phases of outbreaks, respectively, while the remaining country only sampled during the subacute phase. However, in some countries sampling was also done prior to vaccination (2), post vaccination (1), for research (3) and for surveillance (1). In nine of the 13 countries/regions, sampling was done within 1-6 days after a report of a new outbreak.

Ethiopia exclusively used technicians for sampling, while in Djibouti, Puntland, Somalia, Somaliland and South Sudan field veterinarians participated in the sampling together with the technicians. In other countries (7), officials from NRLs were involved in sampling, either exclusively (Rwanda and Sudan) or together with various combinations of field veterinarians, technicians, animal husbandry officers and officers from zonal veterinary investigation centres/researchers (Burundi, Eritrea, Kenya, Tanzania and Uganda). With the exception of Puntland, all people involved in sampling had been trained in FMD sampling. Serum was collected in all countries, either exclusively (3) or in addition to a combination of lesion epithelium/vesicular fluids, oropharyngeal fluids, oral swabs, saliva and whole blood (10). Of the 12 respondents that answered the question on the annual number of samples, three, four, one and four NRLs indicated that <100, 101-500, 501-1000 and $>1000$ samples were collected, respectively (Table 4). It took 1-7 days for samples to get to the NRLs and all the 11 respondents who answered the question on sample storage during transit, indicated that samples were kept

Table 3 FMD control strategies in Eastern Africa

\begin{tabular}{|c|c|c|}
\hline $\begin{array}{l}\text { Country/ } \\
\text { region }\end{array}$ & $\begin{array}{l}\text { Self assessed stage on } \\
\text { PCP-FMD }\end{array}$ & $\begin{array}{l}\text { Existing FMD control } \\
\text { strategies }\end{array}$ \\
\hline Burundi & 0 & quarantine \\
\hline Djibouti & na & quarantine \\
\hline Eritrea & 0 & vaccination $^{a}$ \\
\hline Ethiopia & 1 & vaccination $^{b}$ \\
\hline Kenya & 1 & quarantine, vaccination $^{\mathrm{a}, \mathrm{b}}$ \\
\hline Puntland & 2 & quarantine, vaccination $^{b}$ \\
\hline Rwanda & 3 & quarantine, vaccination $^{b}$ \\
\hline Somalia & 1 & quarantine \\
\hline Somaliland & 1 & quarantine \\
\hline South Sudan & na & none \\
\hline Sudan & 1 & quarantine \\
\hline Tanzania & $\mathrm{nr}$ & quarantine, vaccination $^{\mathrm{a}, \mathrm{b}}$ \\
\hline Uganda & 0 & quarantine, vaccination $^{b}$ \\
\hline
\end{tabular}

na: not assessed, nr: NRL did not reply to this question, a: pre outbreak (preventive) vaccination, b: post outbreak ring vaccination. 
Table 4 FMD sampling in Eastern Africa

\begin{tabular}{|c|c|c|c|c|c|}
\hline $\begin{array}{l}\text { Country/ } \\
\text { region }\end{array}$ & $\begin{array}{l}\text { Reporting time for } \\
\text { sampling (days) }\end{array}$ & $\begin{array}{l}\text { When sampling is } \\
\text { done }\end{array}$ & $\begin{array}{l}\text { Samples } \\
\text { collected }\end{array}$ & $\begin{array}{l}\text { Number of samples } \\
\text { Collected annually }\end{array}$ & $\begin{array}{l}\text { Duration of transport of } \\
\text { samples (days) }\end{array}$ \\
\hline Burundi & $1-6$ & $A C$ & Serum, LEF & $101-500$ & $1-2$ \\
\hline Djibouti & 14 & SAC & Serum & $<100$ & 3 \\
\hline Eritrea & $21-30$ & $\mathrm{AC}, \mathrm{CH}$ & Serum, LEF & $>1000$ & $1-3$ \\
\hline Ethiopia & $1-6$ & $A C$ & Serum, LEF, OP & $<100$ & $2-7$ \\
\hline Kenya & $1-6$ & $\begin{array}{l}A C \text {, post } \mathrm{V} S A C, C H \text {, } \\
\text { Res, pre } V,\end{array}$ & Serum, LEF, OP & $101-500$ & $1-2$ \\
\hline Puntland & $1-6$ & $A C$ & Serum, LEF, OS & $>1000$ & $2-3$ \\
\hline Rwanda & $1-6$ & $A C$ & Serum & $501-1000$ & 1 \\
\hline Somalia & $1-6$ & $A C, S A C$ & Serum, LEF & $>1000$ & $3-4$ \\
\hline Somaliland & $1-6$ & $A C, S A C$ & Serum, LEF & $>1000$ & $3-4$ \\
\hline $\begin{array}{l}\text { South } \\
\text { Sudan }\end{array}$ & $1-6$ & $A C, S A C$ & Serum & $<100$ & $1-2$ \\
\hline Sudan & 7 & $\mathrm{AC}, \mathrm{SAC}, \mathrm{CH}$ & Serum, LEF, OP & $\mathrm{nr}$ & $1-3$ \\
\hline Tanzania & $2-14$ & $\mathrm{AC}, \mathrm{SAC}, \mathrm{CH}$, Res & $\begin{array}{l}\text { Serum, LEF,OP, } \\
\text { OS, WB }\end{array}$ & $101-500$ & $1-2$ \\
\hline Uganda & $1-6$ & $A C, C H$, pre $\vee$ Res, Sur & $\begin{array}{l}\text { Serum, LEF, OP, } \\
\text { OS, SA }\end{array}$ & $101-500$ & $1-2$ \\
\hline
\end{tabular}

AC: acute phase of outbreak, SAC: sub acute phase of outbreak, $\mathrm{CH}$ : chronic phase of outbreak, pre V: pre - outbreak vaccination, post V: post outbreak vaccination, Res: research, Sur: surveillance, LEF: lesion epithelium/fluid, OP: oropharyngeal fluids, OS: oral swabs, SA: saliva, WB: whole blood, nr: NRL did not reply to this question.

Table 5 Reasons for diagnosis of FMD and tests performed at the NRLs and at the collaborating laboratories

\begin{tabular}{|c|c|c|c|c|c|c|}
\hline \multirow[t]{2}{*}{$\begin{array}{l}\text { Country/ } \\
\text { region }\end{array}$} & \multirow{2}{*}{$\begin{array}{l}\text { Reasons for } \\
\text { diagnosis of } \\
\text { FMD }\end{array}$} & \multicolumn{2}{|c|}{ Tests performed at NRLs } & \multirow[t]{2}{*}{ Collaborating laboratories } & \multicolumn{2}{|c|}{$\begin{array}{l}\text { Test performed through } \\
\text { Collaboration }\end{array}$} \\
\hline & & Serology & $\begin{array}{l}\text { FMDV } \\
\text { identification }\end{array}$ & & Serology & FMDV identification \\
\hline Burundi & Cob & ELISA & Ag ELISA & $\mathrm{nc}$ & & \\
\hline Djibouti & Sur, Mve & NSP & - & LQCD, Djibouti & NSP LPBE & $P C R^{a}$ \\
\hline Eritrea & Sur & $\begin{array}{l}\text { SPCE, LPBE, } \\
\text { NSP }\end{array}$ & $P C R^{b}, V I$ & IAH,Pirbright, UK & - & $\begin{array}{l}\text { Ag ELISA, PCR }{ }^{a}, \mathrm{VI}, \\
\text { sequencing }\end{array}$ \\
\hline Ethiopia & Sur, Vmat, Res & LPBE, NSP & $\mathrm{Ag}$ ELISA, PCR $\mathrm{R}^{\mathrm{a}, \mathrm{b}}$ & IAH, Pirbright, UK & - & $P C R$ a,b,$V I$, Sequencing \\
\hline Kenya & $\begin{array}{l}\text { Sur, Vmat, Cob, } \\
\text { Mve, Res }\end{array}$ & $\begin{array}{l}\text { VNT, LPBE, } \\
\text { NSP }\end{array}$ & $\begin{array}{l}\text { Ag ELISA, CFT, } \\
P C R^{b *}, V I\end{array}$ & IAH Pirbright, UK & - & $\begin{array}{l}\text { Ag ELISA, PCR a,b, } \\
\text { Sequencing }\end{array}$ \\
\hline Puntland & Sur, Vmat, & VNT & Ag ELISA & FNL, Kenya & VNT & - \\
\hline Rwanda & Sur, Vmat, Cob & LPBE & - & OVI, South Africa Pirbright, UK & LPBE & Ag ELISA, PCR ${ }^{a, b}$ \\
\hline Somalia & Sur, Vmat & NSP & - & FNL, Kenya & - & Ag ELISA \\
\hline Somaliland & Sur, Vmat & NSP & - & FNL, Kenya & - & $\mathrm{Ag}$ ELISA \\
\hline $\begin{array}{l}\text { South } \\
\text { Sudan }\end{array}$ & Sur, Vmat, Cob & - & Ag ELISA & FNL, Kenya & - & $P C R^{a, b * *}$, Sequencing ${ }^{* *}$ \\
\hline Sudan & $\begin{array}{l}\text { Sur, Vmat, Cob, } \\
\text { Res }\end{array}$ & $\begin{array}{l}\text { VNT, LPBE, } \\
\text { NSP }\end{array}$ & $\mathrm{Ag}$ ELISA, VI & IAH, Pirbright, UK & $\begin{array}{l}\text { VNT, LPBE, } \\
\text { SPCE }\end{array}$ & $\begin{array}{l}\text { Ag ELISA, PCR }{ }^{a, b}, \mathrm{Vl} \text {, } \\
\text { Sequencing }\end{array}$ \\
\hline Tanzania & Sur,Vmat, Cob, Res & $\begin{array}{l}\text { SPCE, LPBE, } \\
\text { NSP }\end{array}$ & Ag ELISA, PCR a,b* & BVI, Botswana IAH, Pirbright, UK & NSP & $\begin{array}{l}\text { Ag ELISA, PCR a,b }, \mathrm{VI} \\
\text { Sequencing }\end{array}$ \\
\hline Uganda & $\begin{array}{l}\text { Sur, Vmat, Cob, } \\
\text { Res }\end{array}$ & $\begin{array}{l}\text { SPBE, LPBE, } \\
\text { NSP }\end{array}$ & $P C R^{a, b}$ & $\begin{array}{l}\text { Lindholm, Denmark IAH, Pirbright, UK } \\
\text { OVI, South Africa }\end{array}$ & VNT & Ag ELISA, sequencing, $\mathrm{VI}$ \\
\hline
\end{tabular}

Cob: confirmation of outbreaks, Sur: surveillance, Mve: monitoring vaccine efficacy, Vmat: vaccine matching, Res: research, PCR: Polymerase Chain Reaction, ${ }^{a}$ : real time PCR, ${ }^{\text {b }}$ : conventional PCR, Vl: virus isolation, Ag: antigen, CFT: complement fixation test, LPBE: liquid phase blocking ELISA, NSP: non-structural protein based antibody ELISA, SPBE: solid phase blocking ELISA, SPCE: solid phase competition ELISA, VNT: virus neutralization test, *:not used for diagnostic but undergoing validation, -: not done, ${ }^{* *}:$ Tests performed by IAH, Pirbright, UK through the collaborating laboratory, nc: no collaboration, LQCD: Lab quarantin center-Dammerjog. 
in cool boxes on ice packs, while three also used liquid nitrogen tanks for storage of virus containing samples.

\section{Diagnosis and confirmation of FMD in the NRLs}

All 13 NRLs were able to diagnose FMD but the reasons for diagnosis of FMD varied: surveillance (12), serotype/ vaccine matching (10), confirmation of outbreaks (7), monitoring of vaccine efficacy (2) and research (5) (Table 5). Confirmation of FMD by NRLs was considered a public good in all countries except Burundi, South Sudan and Tanzania (data not shown). The estimated cost for diagnosis of FMD was less than US\$50 per sample in all but Eritrea and Rwanda which estimated the cost at more than US\$100 (data not shown). The cost for FMD diagnosis was paid by the budgets of NRLs (4), NGO/projects (3) and the ministry either exclusively (3) or in combination with NRLs (1) or projects (2), while in the three countries where FMD diagnosis was not considered a public good, the cost of the services was charged to the submitting body (data not shown).

Table 5 summarises the diagnostic tests performed by the NRLs. All but CDL of South Sudan used serological diagnostic tests. Only three NRLs (Eritrea, Kenya and Sudan) used virus isolation, eight used immunological detection methods including CDL of South Sudan which exclusively used antigen ELISA and three used nucleic acid recognition method (PCR). Table 5 also shows the collaborating laboratories and tests they perform on behalf of the NRLs. All except BNVL of Burundi had collaborations with other laboratories, and the highest level of collaboration (58\%) was registered with the Institute for Animal Health (IAH), Pirbright. The tests provided by the collaborating laboratories were mostly nucleic acid recognition methods (9), while five, eight and six NRLs also requested for virus isolation, Antigen ELISA and serological tests, respectively.

\section{Quality assurance and standardization for FMD in the NRLS \\ Quality management systems (QMS), biosafety and biosecurity in the NRLS}

Eight of the 12 NRLs (67\%) that responded to the question on existence of QMS, indicated they existed, while four did not have QMS in place (Table 6). None of the NRLs had been accredited for FMD diagnosis but all except BNVL in Burundi had standard operating procedures (SOP) for FMD diagnosis. Only four of 13 NRLs (31\%) participated in annual proficiency tests, while four other NRLs had participated in inter-laboratory testing within the region (Table 6). With regard to biosafety level, most NRLs worked at BSL 1-2, while two (FNL in Kenya and NAHDIC in Ethiopia) were at BSL 3 (Table 6). Five of the NRLs (FNL in Kenya, NAHDIC in Ethiopia, CDL in South Sudan, GCVL in Puntland and NAPHL in Eritrea) had biosafety /biosecurity manuals in place (data not shown).

\section{Equipment servicing and maintenance}

Five out of the 13 NRLs (38\%) did not regularly service the equipment used in the diagnostic tests for FMD

Table 6 Quality management systems (Biosafety levels and quality assessment, equipment maintenance and staffing) among Eastern Africa NRLs

\begin{tabular}{|c|c|c|c|c|c|c|c|c|c|c|}
\hline \multirow{2}{*}{$\begin{array}{l}\text { Country/ } \\
\text { Region }\end{array}$} & \multirow{2}{*}{$\begin{array}{l}\text { Bio } \\
\text { safety } \\
\text { Level } \\
\text { (BSL) }\end{array}$} & \multicolumn{3}{|c|}{ Quality assessment } & \multicolumn{3}{|c|}{ Equipment maintenance } & \multicolumn{3}{|l|}{ Staff present } \\
\hline & & QMS & $\begin{array}{l}\text { Proficiency } \\
\text { testing }\end{array}$ & $\begin{array}{l}\text { Inter } \\
\text { laboratory } \\
\text { testing }\end{array}$ & $\begin{array}{l}\text { Regular } \\
\text { servi- } \\
\text { cing }\end{array}$ & Calibration & $\begin{array}{l}\text { Monitoring of } \\
\text { sample storage } \\
\text { daily }\end{array}$ & $\begin{array}{l}\text { Veterinarian/ } \\
\text { scientific } \\
\text { supervisor }\end{array}$ & $\begin{array}{l}\text { Technical } \\
\text { supervisors } \\
\text { (manager) }\end{array}$ & Technicians \\
\hline Burundi & 1 & $\mathrm{nr}$ & - & + & - & - & - & + & - & + \\
\hline Djibouti & 2 & - & - & - & + & + & - & + & - & + \\
\hline Eritrea & 2 & + & - & - & - & - & + & + & + & + \\
\hline Ethiopia & 3 & + & + & - & + & + & + & + & + & + \\
\hline Kenya & 3 & + & + & - & + & - & + & + & + & + \\
\hline Puntland & good & - & - & + & + & + & + & - & + & - \\
\hline Rwanda & 2 & - & - & - & - & - & + & + & + & + \\
\hline Somalia & low & + & - & + & + & + & - & - & - & + \\
\hline $\begin{array}{l}\text { Somali } \\
\text { land }\end{array}$ & good & + & - & + & + & + & - & - & - & + \\
\hline $\begin{array}{l}\text { South } \\
\text { Sudan }\end{array}$ & 1 & - & + & - & + & - & + & + & + & - \\
\hline Sudan & 2 & + & - & - & + & + & - & + & + & + \\
\hline Tanzania & 2 & + & - & - & - & - & - & + & - & + \\
\hline Uganda & 2 & + & + & - & - & - & + & + & - & + \\
\hline
\end{tabular}

+: yes, -: no, nr: NRL did not reply to this question. 
(Table 6), while it was serviced once a year by seven NRLs and twice a year by one NRL (CDL, South Sudan). Six NRLs (46\%) calibrated their laboratory equipment yearly and seven monitored their sample storage equipment daily (Table 6).

\section{Staffing and staff development}

Apart from FNL in Kenya, all NRLs reported a problem of understaffing and one (BNVL in Burundi) had no staff development plans. Ten NRLs had veterinary/scientific supervisors (Table 6) with qualifications ranging from bachelor degree to $\mathrm{PhD}$ among their available staff, while three (SOWELPA in Somalia, GCVL in Puntland and CVL in Hargeisa, Somaliland) did not have any University graduates. Seven NRLs had technical supervisors/laboratory managers while six NRLs did not have this middle management level. In five of the seven NRLs with technical supervisors (NAPHIL in Eritrea, FNL in Kenya, GCVL in Puntland, CDL in South Sudan, VRI in Sudan) some of these had only diplomas and certificate qualifications. All NRLs, except CDL of South Sudan and GCVL of Puntland, had technologist/technicians, at four of these including some with only certificate qualification (VRI in Sudan, SOWELPA in Somalia, CVL in Hargeisa, Somaliland and NLADD in Djibouti). Eight NRLs had laboratory assistants of certificate qualification, and six had administrative assistants/support staff (data not shown).

\section{Discussion}

This study showed that FMD is still endemic in the majority of the countries/regions in the Eastern Africa region, and that these countries/regions mainly use quarantine and post outbreak ring vaccination as FMD control strategies. Moreover, the majority of the countries in the region estimated that they were below stage 3 on the PCP-FMD, an important tool for endemic countries to progressively reduce the presence of FMD $[14,15]$.

It has previously been established that disease recognition is essential for any disease control programme [28], and this is particularly relevant for FMD due to the seven FMDV serotypes causing clinically indistinguishable disease [5] and to FMD being easily confused with other viral diseases [29,30]. The present study showed that, in Eastern Africa, the laboratory capacity for FMD, in terms of tests, equipment and skilled manpower, is still limited, and thus all reported outbreaks are not properly serotyped and characterised leading to insufficient knowledge of the regional FMD status. Other factors contributing to unclear FMD status include unwillingness of farmers to pay for diagnosis where it is not a public good (3), and failure (6) or inconsistency (7) in submitting samples to WRLFMD, Pirbright, UK, for free typing, possibly due to logistically complicated and expensive sample shipment [5]. Moreover, three countries had received negative results from WRLFMD, probably due to poor sample quality. Possible reasons for this could be improper handling during the 1-7 day transit from the field to the NRLs, which in 10 of the 13 countries/regions happened in cool boxes with ice packs rather than in liquid nitrogen, or poor quality sample storage in the laboratories caused by unreliable power supplies in most countries/regions. Poor sampling is less likely, since training in sampling technique had been provided in 12 countries/regions, including the three receiving negative results from WRLFMD.

Though three countries in this survey exclusively collected serum during the acute and subacute phases of outbreaks, the majority of the countries/regions followed the recommendation of the OIE [22] and collected samples for demonstration of FMD viral antigen or nucleic acid during the acute phase of outbreaks; moreover, their NRLs had either antigen ELISA or PCR set up. However, success of these tests entirely depends on sample quality determined by timing and handling of samples [1], and a number of outbreaks in the region were not serotyped and/or characterised. All but one of the 13 NRLs relied on antibody ELISAs, most likely because these tests are cheap and suitable for working on many samples, require lower level of biocontainment [22], and neither depend on cell cultures nor on highly sensitive, expensive and service-requiring PCR-equipment [31].

The most widely used antibody ELISAs were tests for identification of antibodies against FMDV non structural proteins (NSP), probably because they are simple and serotype-independent, and thus good screening tests for exposure to FMDV antigen [20,32]. These tests can also differentiate infected from vaccinated animals (DIVA test) [33], however, in Eastern Africa, interpretation of NSP-test results is complicated by the frequent use of non-purified vaccines which elicit antibodies against NSPs, thereby limiting the DIVA application of these tests $[20,34,35]$. Furthermore, antibodies against NSPs do not appear until day 8-9 after infection [36], thus, to be useful, these tests should only be used for sera sampled in the late subacute and chronic phases. Moreover, as demonstrated in both small ruminants [37] and cattle [33], antibodies against NSPs persist for a long time, and thus NSP ELISAs do not differentiate well between present and past infection at individual level.

Eight of the 13 NRLs serotyped antibodies against FMDV using OIE-recommended tests, i.e. VNT (3), LPBE (7) and SPCE (1), and one of these also used a comparable in-house SPBE developed at the National Veterinary Institute, Lindholm, Denmark [38]. The limited use of VNT is most likely due to lack of cell culture facilities, and possibly also to most NRLs working at 
BSL 2-level. All available serotype-specific antibody tests, including VNT, show cross reactions [39-41], which have grave implications for the control of FMD in the Eastern Africa countries that greatly rely on serology for serotyping of outbreaks. In endemic situations such cross reactions may be more pronounced due to repeated vaccination against and/or infection with one or more FMDV serotypes [42,43]. Moreover, test related crossreactivity has been demonstrated for SPBEs in samples collected 1-3 weeks after experimental infection of naive calves (unpublished results) and in field sera from unvaccinated small ruminants [44], and for LBPE in sera from bovines [39], hence, there is a need to improve the specificity of the existing serotype-specific antibody ELISAs.

Tests for detection of FMDV can either identify the serotype directly (antigen ELISA and sequencing) or in combination with other techniques (VI and PCR). In this study, nine NRLs had the capacity for the detection of FMDV while the remaining four NRLs relied on sending samples abroad for antigen ELISA (3) or to another national laboratory for PCR (1). The most widespread test was the antigen ELISA (7), which like the serotypespecific antibody ELISAs, shows cross reactions between the FMDV serotypes [45]. The phasing out of the CFT in the region demonstrates a move towards more modern methods, which is also evident from the five NRLs already using or introducing PCR. Only three NRLs used VI despite this being about as sensitive as PCR [31,46], most likely for the same reasons as for not using VNT. Equally few NRLs (3) used real time and/or conventional RT-PCR in routine diagnosis, which accords with findings in another endemic country, Brazil, where limited use was attributed to lack of infrastructure, high cost and anticipated problems of maintaining technically complicated and service-demanding PCR machines [31].

The majority of the NRLs (12) collaborated with foreign laboratories, including WRLFMD in UK, OVI in South Africa and FNL in Kenya, to complement their own diagnostic services. However, Rweyemamu et al. [15] maintained that relying on foreign technical assistance to manage disease control programs may not be sustainable in developing countries, and experience from the region confirms this as the number of samples analysed is insufficient to get adequately detailed knowledge of the circulating FMDV strains to implement sufficiently efficient control measures to reduce FMD in the region. Moreover, recent evidence of the transboundary nature of FMD in Eastern Africa [9] points to a need for assuming a regional approach to achieve more efficient control of FMD and progress on the PCP-FMD.

Eight NRLs had a quality management system (QMS) in place and had participated in laboratory comparisons, either inter-laboratory tests or proficiency tests. In Europe, QMSs are considered essential for diagnosis of
FMD $[47,48]$ including focus on competent, motivated staff, organisational management, functional equipment, process control and biosafety/biosecurity [49]. In the Eastern Africa region, although only one of the 13 NRLs entirely lacked SOPs, all had deficient QMS as equipment was not regularly serviced in five and not calibrated in six NRLs, and six did not monitor sample storage equipment daily. This can lead to unreliable equipment and inconsistent quality of samples, which may affect the results of the performed tests [48]. Moreover, none of the NRLs had been accredited for FMD diagnosis, including those in countries with vaccine production plants, and most laboratory comparisons were arranged by laboratories outside the region with a more worldwide focus. Thus, QMS efforts could be strengthened substantially by setting up a regional reference laboratory for FMD, which would arrange local comparative inter-laboratory tests with relevance for the region, encourage QMS and promote virus characterisation among the NRLs [25].

Many diagnostic laboratories also have consultative/ advisory and disease surveillance roles [28], and its recommended to build a team of national experts for these tasks [15]. However, in this study, 12 NRLs were understaffed, disclosing a clear regional need to address capacity building in terms of laboratory space, equipment and training of professional and technical staff, as is currently being carried out by collaborative projects in Uganda and Kenya (TADEA, DANIDA-funded) and in Tanzania (SADC TADs, Wellcome Trust- funded), and as has been initiated for the entire region by FAO organizing the NRLs into a network (EARLN).

OIE recommends that FMD diagnosis is carried out in OIE class 4 facilities [25,50] and this is generally adhered to in the FMD-free countries. However, most Eastern African NRLs were working below BSL 3 including seven NRLs undertaking virological tests to diagnose FMD. Moreover, the recommendations for developing biosafety manuals and adopting biosafety policies [51], were only implemented at five NRLs. The low level of biosafety and biosecurity measures could result in escape of FMDV as happened in the 2007 UK FMD outbreak [52], and it may be speculated that a (presumably small) proportion of the outbreaks in Eastern Africa may be due to poor laboratory biocontainment.

\section{Conclusions}

The overall status of FMD in the region remains obscure due to insufficient diagnostic capacity, leading to lack of regular typing of outbreak strains. The NRLs largely depend on antigen and antibody ELISAs, supplemented by varying levels of virus identification and characterisation performed by international laboratories; moreover, they do not prioritize QMSs and none of them are accredited 
for FMD diagnosis. This calls for improvements at the NRLs, including training of personnel and upgrading equipment and diagnostic methods, to ensure accurate, reliable and correctly interpreted results. More reliable results would also provide an enhanced background for more narrow selection of vaccine strains/serotypes, which would reduce costs of FMD vaccination campaigns and could lead to increased numbers of vaccinated animals.

Moreover, a regionally coordinated FMD control strategy should be implemented to ascertain sustainable impact of national efforts to improve according to the PCP-FMD, including the establishment of a regional reference laboratory to oversee QMS and promote the characterization of FMDV.

\section{Additional file}

\section{Additional file 1: Questionnaire on Laboratory capacity for Foot} and Mouth Disease (FMD) Diagnosis in Eastern Africa.

\section{Competing interests}

The authors declare that they have no competing interests.

\section{Authors' contributions}

AN, SNW \& CA conceived and designed the study; AN was responsible for data analysis, manuscript preparation, review, corrections and submission. SNW further participated in data collection and manuscript reviews; MTD, VBM, KT, HRS \& CA participated in the supervision of data analysis and manuscript preparation and critical revision. All authors read and approved the final manuscript.

\section{Acknowledgements}

This study was funded by Danish International Development Agency (DANIDA) under the Transboundary Animal Disease of East Africa (TADEA) project (Project number:10-006KU). Special thanks are due to the contact persons of the 13 responding NRLs of the EARLN and to Mr. Bernard Mwesigwa of FAO Uganda for the assistance in drawing the map.

\section{Author details \\ ${ }^{1}$ National Animal Disease Diagnostics and Epidemiology Centre, Ministry of Agriculture Animal Industry and Fisheries, P. O. Box 513, Entebbe, Uganda. ${ }^{2}$ Department of Biotechnical and Diagnostic Sciences, College of Veterinary Medicine, Animal Resources and Biosecurity, Makerere University, P. O. Box 7062, Kampala, Uganda. ${ }^{3}$ Department of Environmental Management, College of Agricultural and Environmental Sciences, Makerere University, P. O Box 7062/7298, Kampala, Uganda. ${ }^{4}$ Foot-and-Mouth Disease Laboratory, Ministry of Livestock Development, P.O. Box 18021, Embakasi, Nairobi, Kenya. ${ }^{5}$ National Veterinary Institute, Technical University of Denmark, Lindholm, Kalvehave DK 4771, Denmark. ${ }^{6}$ Department of Biology, Ole Maaløes Vej 5, Copenhagen N DK-2200, Denmark.}

Received: 14 September 2012 Accepted: 16 January 2013 Published: 24 January 2013

\section{References}

1. Alexandersen S, Mowat N: Foot-and-mouth disease: host range and pathogenesis. Curr Top Microbiol Immunol 2005, 288:9-42.

2. Kitching RP: Clinical variation in Foot and Mouth Disease: Cattle. Rev Sci Tech Off int Epiz 2002, 21:499-504.

3. Rweyemamu MM, Leforban Y: Foot-and-Mouth Disease and International Developments. Adv Virus Res 1999, 53:111.

4. Stanway G, Brown F, Christian P, Hovi T, Hyypia T, King AMQ, Knowles NJ, Lemon SM, Minor PD, Pallansch MA, et al: Family Picornaviridae. In Virus
Taxonomy: classification and nomenclature of viruses Eighth Report of the International Committee on Taxonomy of Viruses. Edited by Fauquet CM, Mayo MA, Maniloff J, Desselberger U, Ball LA. London: Elsevier/Academic Press; 2005:757-778.

5. Vosloo W, Bastos AD, Sangare O, Hargreaves SK, Thomson GR: Review of the status and control of foot and mouth disease in sub-Saharan Africa. Rev Sci Tech 2002, 21:437-449.

6. Rweyemamu M, Roeder P, Mackay D, Sumption K, Brownlie J, Leforban Y, Valarcher JF, Knowles NJ, Saraiva V: Epidemiological patterns of foot-andmouth disease worldwide. Transbound Emerg Dis 2008, 55:57-72.

7. Ayebazibwe C, Mwiine FN, Tjørnehøj K, Balinda SN, Muwanika VB, Ademun Okurut AR, Belsham JB, Normann P, Siegismund HR, Alexandersen S: The role of African buffalos (syncerus caffer) in the maintenance of foot-andmouth disease in Uganda. BMC Vet Res 2010, 6:1-13.

8. Ayelet G, Mahapatra M, Gelaye E, Egziabher BG, Rufeal T, Sahle M, Ferris NP, Wadsworth J, Hutchings GH, Knowles NJ: Genetic characterization of footand-mouth disease viruses, Ethiopia, 1981-2007. Emerg Infect Dis 2009, 15:1409-1417

9. Balinda SN, Sangula AK, Heller R, Muwanika VB, Belsham GJ, Masembe C, Siegismund HR: Diversity and transboundary mobility of serotype $O$ footand-mouth disease virus in East Africa: implications for vaccination policies. Infect Genet Evol 2010, 10:1058-1065.

10. Habiela M, Ferris NP, Hutchings GH, Wadsworth J, Reid SM, Madi M, Ebert K, Sumption KJ, Knowles NJ, King DP, Paton DJ: Molecular characterization of foot-and-mouth disease viruses collected from Sudan. Transbound Emerg Dis 2010, 57:305-314.

11. Roeder PL, Knowles NJ: Foot-and-mouth disease virus type C situation: the first target for eradication, The Global Control of FMD - Tools, Ideas and Ideals. Erice, Italy: FAO, Rome; 2009.

12. Sangula AK, Siegismund HR, Belsham GJ, Balinda SN, Masembe C, Muwanika VB: Low diversity of foot-and-mouth disease serotype $C$ virus in Kenya: evidence for probable vaccine strain re-introductions in the field. Epidemiol Infect 2010, 139:189-196.

13. Kitching $P$, Hammond J, Jeggo M, Charleston B, Paton D, Rodriguez $L$, Heckert R: Global FMD control-is it an option? Vaccine 2007, 25:5660-5664

14. FAO/OIE: Principles, Stage description and Standards, The Progressive Control Pathway for FMD control (PCP-FMD). 2011. http: //www.faoorg/ag/againfo/ commissions/docs/PCP/PCP-26012011pdf.

15. Rweyemamu M, Roeder P, MacKay D, Sumption K, Brownlie J, Leforban Y: Planning for the progressive control of foot-and-mouth disease worldwide. Transbound Emerg Dis 2008, 55:73-87.

16. Hunter P: Vaccination as a means of control of foot-and-mouth disease in sub-saharan Africa. Vaccine 1998, 16:261-264.

17. Rweyemamu MM: Foot and mouth disease control strategies in Africa. Prev Vet Med 1984, 2:329-340.

18. Ayebazibwe C, Tjornehoj K, Mwiine FN, Muwanika VB, Okurut AR, Siegismund HR, Alexandersen S: Patterns, risk factors and characteristics of reported and perceived foot-and-mouth disease (FMD) in Uganda. Trop Anim Health Prod 2010, 42:1547-1559.

19. Sangula AK, Belsham GJ, Muwanika VB, Heller R, Balinda SN, Siegismund HR: Co-circulation of two extremely divergent serotype SAT 2 lineages in Kenya highlights challenges to foot-and-mouth disease control. Virol 2010, 155:1625-1630.

20. Sutmoller P, Barteling SS, Olascoaga RC, Sumption JK: Control and eradication of foot-and-mouth disease. Virus Res 2003, 931:101-144.

21. Paton DJ, Valarcher JF, Bergmann I, Matlho OG, Zakharov VM, Palma EL, Thomson GR: Selection of foot and mouth disease vaccine strains-a review. Rev Sci Tech 2005, 24:981-993.

22. OIE: Foot and Mouth Disease [chapter 2.1.5]. In Manual of standards for diagnostic tests and vaccines for terrestrial animals. Edited by Commission OS; 2009.

23. Mumford JA: Vaccines and viral antigenic diversity. Rev Sci Tech 2007, 26:69-90.

24. Donaldson Al, Astudillo V: The role of reference and regional laboratories In Vaccine manual: the production and quality control of veterinary vaccines for use in developing countries. Edited by Mowat N, RWEYEMAMU MM. Rome: FAO; 1997:317-326.

25. Edward S, Alexander D, Edward S, Alexander D: National and International Veterinary Reference Laboratories for infectious diseases. Rev sci tech Off int Epiz 1998, 17:418-425. 
26. WRLFMD: Annual OIE/FAO FMD Reference Laboratory Network Reports, FAO World Reference Laboratory for Foot-and-Mouth Disease. 2012. http://www. wrlfmd.org/ref_labs/fmd_ref_lab_reports.htm. Accessed:07/03/2012.

27. NCBI: DNA \& RNA nucleotide database - FMDV. 2011. http://www.ncbi.nlm nih.gov/nuccore?term=FMDV. Accessed: 3/9/2011.

28. Saliki JT: The role of diagnostic laboratories in disease control. Ann N Y Acad Sci 2000, 916:134-138.

29. Kitching RP, Hughes GJ: Clinical variation in Foot and Mouth Disease: Sheep and goats Rev Sci Tech Off int Epiz 2002, 21:505-512.

30. Holliman A: Differential diagnosis of diseases causing oral lesions in Cattle. In Practice (Journal of the British Veterinary Association) 2005, 27:2-13.

31. Paixao TA, Neta AV, Paiva NO, Reis JR, Barbosa MS, Serra CV, Silva RR, Beckham TR, Martin BM, Clarke NP, et al: Diagnosis of foot-and mouth disease by real time reverse transcription polymerase chain reaction under field conditions in Brazil. BMC Vet Res 2008, 4:53.

32. Paton DJ, de Clercq K, Greiner M, Dekker A, Brocchi E, Bergmann I, Sammin DJ, Gubbins S, Parida S: Application of non-structural protein antibody tests in substantiating freedom from foot-and-mouth disease virus infection after emergency vaccination of cattle. Vaccine 2006, 24:6503-6512

33. Sørensen KJ, Madsen KG, Madsen ES, Salt JS, Naindi J, MACKAY DKJ: Differentiation of infection from vaccination in foot-and-mouth disease by detection of antibodies to the non-structural proteins $3 D, 3 A B$ and $3 A B C$ in ELISA using antigens expressed in baculovirus. Arch Virol 1998, 8:1461-1476.

34. Ayebazibwe C, Mwiine FN, Balinda SN, Tjornehoj K, Alexandersen S: Application of the Ceditest(R) FMDV type $\mathrm{O}$ and FMDV-NS enzymelinked immunosorbent assays for detection of antibodies against Foot-and-mouth disease virus in selected livestock and wildlife species in Uganda. J Vet Diagn Invest 2012, 24:270-276.

35. Lee $F$, Jong MH, Yang DW: Presence of antibodies to non-structural proteins of foot-and-mouth disease virus in repeatedly vaccinated cattle. Vet Microbiol 2006, 115:14-20.

36. Lu Z, Cao Y, Guo J, Qi S, Li D, Zhang Q, Ma J, Chang H, Liu Z, Liu X, Xie Q: Development and validation of a $3 A B C$ indirect ELISA for differentiation of foot-and-mouth disease virus infected from vaccinated animals. Vet Microbiol 2007, 125:157-169.

37. Paton DJ, Ferris NP, Hutchings GH, Li Y, Swabey K, Keel P, Hamblin P, King DP, Reid SM, Ebert K, et al: Investigations into the cause of foot-andmouth disease virus seropositive small ruminants in Cyprus during 2007. Transbound Emerg Dis 2009, 56:321-328.

38. Have $P$, Jensen HM: Detection of antibodies to foot-and-mouth disease virus type $O$ by enzyme linked immunosorbent assay (ELISA). In Report of the session of the Research Group of the Standing Technical Committee of the European Commission for the Control of Foot-and-Mouth Disease; 20-22 September, 1983 Lelystad, Netherlands.; 1983:44-51. Appendix VIII.

39. Hamblin C: Barnett ITR, Hedger RS: A new enzyme-linked immunosorbent assay (ELISA) for the detection of antibodies against foot-and-mouth disease virus. I. Development and method of ELISA J Immunol Methods 1986, 93:115-121.

40. Mackay DK, Bulut AN, Rendle T, Davidson F, Ferris NP: A solid-phase competition ELISA for measuring antibody to foot-and-mouth disease virus. J Virol Methods 2001, 97:33-48.

41. Mwiine FN, Ayebazibwe C, Olaho-Mukani W, Alexandersen S, Balinda SN, Masembe C, Okurut AR, Christensen LS, Sorensen KJ, Tjornehoj K: Serotype specificity of antibodies against foot-and-mouth disease virus in cattle in selected districts in Uganda. Transbound Emerg Dis 2010, 57:365-374.

42. Mwiine FN, Ayebazibwe C, Alexandersen S, Olaho-Mukani W, Okurut Ademun AR, Tjørnehøj K: Seroepidemiological investigation of foot-andmouth disease virus serotypes in cattle around Lake Mburo National Park in South- western Uganda Journal of Veterinary Medicine and Animal Health 2010, 2:46-54

43. Hedger RS, Barnett ITR, Gradwell DV: Travassos Dias P: Serological tests for foot and mouth disease in bovine serum samples. Problems of interpretation. Rev sci tech off int Epiz 1982, 1:387-393.

44. Balinda SN, Tjornehoj K, Muwanika VB, Sangula AK, Mwiine FN, Ayebazibwe C, Masembe C, Siegismund HR, Alexandersen S: Prevalence estimates of antibodies towards foot-and-mouth disease virus in small ruminants in Uganda. Transbound Emerg Dis 2009, 56:362-371.

45. Ferris NP, Abrescia NG, Stuart DI, Jackson T, Burman A, King DP, Paton DJ: Utility of recombinant integrin alpha $v$ beta6 as a capture reagent in immunoassays for the diagnosis of foot-and-mouth disease. J Virol Methods 2005, 127:69-79.

46. Alonso A, Martins MA: Gomes Mda P, Allende R, Sondahl MS: Foot-andmouth disease virus typing by complement fixation and enzyme-linked immunosorbent assay using monovalent and polyvalent antisera. J Vet Diagn Invest 1992, 4:249-253.

47. Leforban Y: Assessment of needs of national FMD laboratories for quality assurance for FMD diagnosis, In Report of the Research Group of the Standing Technical Committee of the European Commission for the Control of Foot and Mouth Disease. Rome: FAO; 1995:61-73. 61-73.

48. De Clercq K, Goris N, Barnett PV, MacKay DK: The importance of quality assurance/quality control of diagnostics to increase the confidence in global foot-and-mouth disease control. Transbound Emerg Dis 2008, 55:35-45.

49. WHO: Laboratory Quality Management System - Training toolkit. Lyon, France: WHO/HSE/IHR/LYO/2009. 1; 2009.

50. OIE: Biosafety and Biosecurity in the Veterinary microbiology laboratory and Animal facilities (CHAPTER 1.1.2 ). 2008. http://www.oie.int/fileadmin/Home/ eng/Health_standards/tahm/1.1.02_BIOSAFETY.pdf.

51. CDC: Biosafety in Microbiological and Biomedical Laboratories. 5th edition. 2009.

52. Rhodes C: Consequences of Failure to Apply International Standards for Laboratory Biosafety and Biosecurity: The 2007 Foot-and- Mouth Disease Outbreak in the UK. Applied Biosafety 2009, 14:144-149.

doi:10.1186/1746-6148-9-19

Cite this article as: Namatovu et al.: Laboratory capacity for diagnosis of foot-and-mouth disease in Eastern Africa: implications for the progressive control pathway. BMC Veterinary Research 2013 9:19.

\section{Submit your next manuscript to BioMed Central and take full advantage of:}

- Convenient online submission

- Thorough peer review

- No space constraints or color figure charges

- Immediate publication on acceptance

- Inclusion in PubMed, CAS, Scopus and Google Scholar

- Research which is freely available for redistribution

Submit your manuscript at www.biomedcentral.com/submit
C Biomed Central 